\title{
CHORAL CONCERTS AS A PART OF EDUCATIONAL PROCESS
}

\section{Milan Pazurik}

doi: 10.18355/PG.2020.9.1.3

\begin{abstract}
Educational concerts of choral and vocal arts area are part of the education process of students in primary and secondary schools in Slovakia. It brings the knowledge and expertise to the expansion of the content of subjects of the music education, music history, musical periods, and other types. It shows to pupils the aim of vocal interpretation, solo, duet, trio, quartet, chorus, choir with accompaniment instrument. It constitutes an element of art to the education and collective training.
\end{abstract}

\section{Key words}

educational concert, singer, conductor, pupil, teacher, music work

\section{Educational concerts theoretically}

We come across educational concerts since our childhood. Almost every child, pupil of elementary or secondary school went through it. Every pupil perceives it individually and subjectively with the aim to have esthetic or artistic experience. Active perception is that kind of listening music, that expects active participation of children listeners with use of elements of creativity. It is based on the need to bring children's percipients by appropriate way the musical work, not only by provided information and quantity of facts, but to provide their active joint with music. By Herden, active perception has two characteristics: own musician's activity, means experience obtained by active singing, by instrumental play, by movement or dramatic action and by mental activity which is based on main mental operations. (Herden, 2010).

Concerts for children and adults have undergone many conceptual changes during the year. Burgova establishes a typology of concerts for children and adults, based on the multiannual research and cooperation with Austrian Institutions:

- classical form concerts with an anchorman, which was the first core research

- concerts with story, known as the musical fairy tales,

- concerts for families with children and operas for children (Burgova, 2007)

According to Drabenek the presence of didactic interaction as an intermediary article of aesthetic interaction is the sign of educational concert. Didactic interaction comes between the teacher, presenter or performer of musical work and pupil, facilitates active contact between the student and artifacts, it means aesthetic interaction. The model of concerts known from the past decades has gradually replaced practice to motivational model, which is "in principle, based on musical experience, behind which are hidden 
educational opportunities, that must prepare and develop the teacher by himself. " (Hrabinova, 2007, p. 43)

Concerts for children have passed through fundamental changes of dramaturgical concept," ranging from classical concerts with accompanying words of presenter, towards musical and scenic shape with a strong emotional impact, supported by an active involvement of the children in the audience and co-star of the children directly on the stage." (Cunderlikova, 2007, p. 40).

Interpretation of musical works - whether vocal, instrumental or musical movement gives space for a formation of "team spirit". It's about creating new opportunities of communication within the group through the plot, or musical interpretation, finding solutions through various imagination, emotional commitment. (Hudakova, J. 2011)

The inclusion of concerts for children into educational activities is just one part of the issue of development of their musicality. Each of them brings new impressions enhanced by authenticity of testimony and environment's atmosphere for the child recipient. Together with aesthetic experience, they deepen student's musical and general education; they increase their level of culturalism and social behavior. For a considerable number of children, it's usually their first and, sometimes the only change, to visit a concert of classical music at all. ${ }^{1}$

\subsection{Educational concerts and educational process}

Marianna Kolostova in her contribution writes.... "Educational objectives should include cognitive, affective and psychomotoric area" and explains":

Cognitive objectives: The students know the basic musical means of expression artificial music of different styles and periods. They know the characteristics of developmental periods of music. They know the information and curiosities of the production and reproduction of music which he relates with interpreted songs and their authors.

Affective objectives: A student can accept artificial music as part of the cultural heritage of the society.

Psychomotoric objectives: The student is able to identify himself as the percipients of artificial music, to work on the perception of music and actively access to perceptual activities.

Educational concert for students, as one of the educational goals, contributes to creating the communicational relationships and skills. Jana Hudakova states: ... "communication between characters of the story, but also communication with" auditorium "or audience gives space for increasing of self-confidence and getting rid of stage fright and uncertainty. "Then states: ... "Besides emotional, artistic and aesthetic, educational and instructional goals, the child is in contact with the musical-educational

\footnotetext{
${ }^{1}$ Elaborated based on contribution of PaedDr. M. Kološtovej, Ph.D. Active perception of art music. Slavonic Pedagogical Studies Journal, Nitra 2015. N. 2. 248-258.
} 
concerts and polyestethics projects of social importance. It is the willingness to participate in the music experiences, share it and to communicate with the music and about music. In the process it's education in the music itself. It is therefore a necessary act for cognitive, emotional and sensorimotor component of personality and it inspires them to their own musical-creative activities. " (Hudakova 2013)

\subsection{Educational concerts in practice.}

Active singing and choral outputs to educational concerts for children and youth carried out regularly at the Pedagogical Faculty in Banska Bystrica with the University choir MLADOST not only at schools, but especially in the areas of primary schools (school canteens, gyms) or for schools in local cultural institutions, theaters and churches.

At the Department of Music Culture PF UMB choral singing is strongly represented in the lesson plan of each student of musical disciplines (currently artistic and educational subjects, study programs) in all classes and combinations, at least in SP School music files. The choir MLADOST resides here (since 1969), consisting only from students, and sometimes also absolvents help out - teachers of music from practice for whom choral singing became a penchant and permanent part of their lives during their studies.

Singing choir Mladost also serves as a training body for the preparation and practical output of the students in their final year as part of the courses conducting and choir management respectively choral conducting and vocal music files.

Each larger study group, respectively class group, made up students of one year, can form a chamber group, capable of presenting to the public in cultural programs and school academies as needed. Currently there work also a department vocal group ZBORHUS - which is made up of students SP SME. ${ }^{2}$ The complex is available to students who end Master degree by practical outcomes, who choose to graduate with diploma thesis and diploma concert in choral conducting. Thus prepared vocal ensembles will also use this kind and type of outputs such as educational choral concerts.

\section{Dramaturgy}

Dramaturgy of mentioned concerts is generally designed in two directions:

- focused on history of music - development respectively introducing individual musical periods, epochs with relevant signs on vocal arts

- focused on the creation of geographic orientation (which dates back to the Middle Ages as anonymous, songs of tramp singers, but especially folk and national songs and songs with folk elements) of individual continents, countries, regions and areas with different customs, traditions and cultural heritage

\footnotetext{
2 (Study program: School's musical ensemble)
}

Slavonic Pedagogical Studies Journal, eISSN 1339-9055, ISSN 1339-8660, Volume 9 Issue 1, 2020 


\section{- Should not miss children's musical}

\subsection{Construction of dramaturgy and preparation of the concert:}

It is a very important component for the construction of a concept of vocal and choral educational concerts. We can include here, for example: track of individual style periods with explanation of characteristic features of individual style periods, the diversity of a specific period (medieval, renaissance, baroque, classicism, romantic, choral songs from operas, musicals, types and forms, popular songs, spirituals etc.)

They should not miss a fairytale's theme songs (The Lion King), songs with children's themes or songs composed by modern techniques, onomatopoeia current vocal means of expression (clusters, noises, uncertain sounds, extra-musical sounds, etc.)

Very popular and frequently used is the "geographic itinerary" tracks, which should focus on individual countries and we should be already familiar with some of their songs. (Ukrainian folk, Polish wedding songs, Hungarian czardas, Czech folk, typical Italian, Greek, French, Estonian's lullaby, Russia, Serbia or Macedonia with $7 / 8$ tact but the Argentinian, American, Mexican folk, etc.). They should not miss the track with solo, composition for solo and choir (female, male, or even both solos).

Types of tracks and their description, introduction of individual voice's groups of choral complex (which should not miss on any of vocal concert) or musical instruments, cultural orientation, historical reflection, specifications of cultural heritage etc. Underline the importance and position of the conductor. Advent's concerts, Christmas or New Year's educational concerts are very specific as well.

The proportion of students in the preparation of educational concerts can be in case of dramaturge concert, compilation of song order, concert moderating a very positive phenomenon, where the student is in the position where he fully prepares for the teaching profession and communication with the audience. This concert may also content "little quiz", which is also attended, made and led by students. Of course, they can't miss the evaluation and praise at the end. Only by that way we can confidently invite auditorium successfully for the next educational concert or its continuation and motivate the teachers of music education.

In conclusion, we can say that according to the results of the educational research (based on confirmed and verification of some hypotheses)

Active perception of art music has an influence on the positive formation of the relation of students in primary level of education to classical music it can bring up potential visitors of concerts and music events.

Perception of art music affects the relationship of students to compositions of classical music.

Active perception affects the openness of students for potential attendance rate of concerts. 
Music pedagogues of different stages and types are convinced about the need for active music perception. In order to make a space for the perception of art music in its formative influence on the personality of students, it is necessary for them to include concerts into the educational activities in elementary school. Educational goals that should fill up that music - educational project, should be come out from the school educational program of individual schools, which defines the objectives, the scope of the subject matter, content and performance standards and subject graduate's competencies. (Kolostova, M. 2015).

Music pedagogues often use the sentence, that clearly importance is described by Balcarova statement: "Making art music perception the child's living need, means to face the one-sidedness of its artistic orientation." (Kalafutova-Balcarova, 2001)

It was confirmed, that choral and vocal educational concerts are extremely necessary and important for upbringing, education and experience, not only for the educational and knowledge orientation, approach to the genre, but also singing and vocal art, classical, popular and folk songs. If this process is interesting, it is also a reflection of the student's and pupil's discipline on an excellent level of attention.

Music can actually change the direction of human's life orientation unless the preparation is intentional, knowing and professional.

\section{Bibliographic references}

BURGROVA, K. 2007. Koncerty pre deti a mládež - výsledky prieskumu v základných školách na Slovensku (Bratislava, Prešov). In Koncerty pre deti a mládež. Prešov: Prešovská Univerzita v Prešove, Pedagogická fakulta, 2007. ISBN 978-80-8068-647-5, p. 110 - 126.

DRABEK, V. 1987. ABC výchovných koncertů. Praha: Divadelní ústav, Praha, 1987. p.124

FELIX, B. 2013. Aktívna percepcia v príprave učitel'ov. In Kontexty hudobnej pedagogiky I. Banská Bystrica: Univerzita Mateja Bela, Pedagogická fakulta 2013. ISBN 978-80-5570553-8, p. 32 - 62.

HERDEN, J. 2010. Aktivní poslech. In Hudba pre deti - multimediálne projekty. Banská Bystrica: Univerzita Mateja Bela, Pedagogická fakulta, 2010. ISBN 978-80-557-0075-5, p. $35-41$.

HRABINOVA, M. 2007. Kritériá Hudobného centra Bratislava pre výchovné koncerty. In Koncerty pre deti a mládež. Prešov: Prešovská univerzita v Prešove, Pedagogická fakulta, 2007. ISBN 978-80-8068-647-5, p. 43 - 44.

HUDAKOVA, J.- SLAVIKOVA, Z. 2009: Emócie v hudbe a výskum l'udského hlasu a spevu. Umění ve službě výchově, prevenci, expresivní terapii: výzkumný záměr Učitelská profese v měnících se požadavcích na vzdělávání Vyd. PF UK Praha 2009, ISBN 978-80-7290-415-0

HUDAKOVA, J. 2014. Hudobno-dramatický projekt študentov hudobného umenia ako inšpirácia pre prácu učitel’a hudobného výchovy na základnej škole. In: Teorie a praxe hudební výchovy III: sborník prŕíspěvků z konference studentů doktorandských a magisterských studií a pedagogů hudebního vzdělávání zemí V4, 2013 Praha: Univerzita Karlova v Praze, Pedagogická fakulta, p. 181-184. ISBN 978-807290-724-3 
KALAFUTOVA - BALCAROVA, B. 2001. Recepcia hudby. Prešov: Súzvuk, 113 p. ISBN 80-968566-4-2.

KOLOSTOVA, M. 2013. Pohl'ad na profiláciu slovenskej hudobnej pedagogiky $\mathrm{v}$ širšom kontexte vývoja spoločnosti $\mathrm{v} 2$. polovici 20. storočia. In: Kontexty hudobnej pedagogiky I. Banská Bystrica : Univerzita Mateja Bela, Pedagogická fakulta ISBN 978-80-557-0553-8, pp. 5-31.

KOLOSTOVA, M. 2015. The active perception of art music at the lower level of secondary school education. In: The Slavonic Pedagogical Studies Journal. Nitra: Slovenska Vzdelavacia a Obstaravacia s.r.o., n. 2, ed. 4. ISSN 1339-9055, pp. 248-258.

KOLOSTOVA, M. - PAPOVA, J. Aktívna percepcia artificiálnej hudby na nižšom sekundárnom stupni vzdelávania.

PAZURIK, M. 1996. Spevácky zbor ako mimoškolská hudobná aktivita v príprave učitel'a, 1. vyd. PF UMB Banská Bystrica, p. 50 . ISBN 8088825-55-5

PAZURIK, M. 2010. Atribúty zborového spevu a ich vplyv na profil absolventov hudobnej výchovy pedagogických fakúlt v Slovenskej republike so zameraním na Katedru hudobnej výchovy Pedagogickej fakulty Univerzity Mateja Bela v B. Bystrici. In: Zborník ACTA HUMANICA 1/2010, Vydala Katedra pedagogických štúdií, Fakulta prírodných vied, Žilinskej Univerzity Žilina 2010, Editor: prof. PhDr. B. Banáry, CSc. p. 167-171, ISSN 1336 5126, Ev 1759/08

prof. PaedDr. Milan Pazúrik, CSc.,

Department of Music Culture PF Universite of Matej Bel

Ružova 13, Banska Bystrica,

Slovakia

milan.pazurik@umb.sk 
Attachement
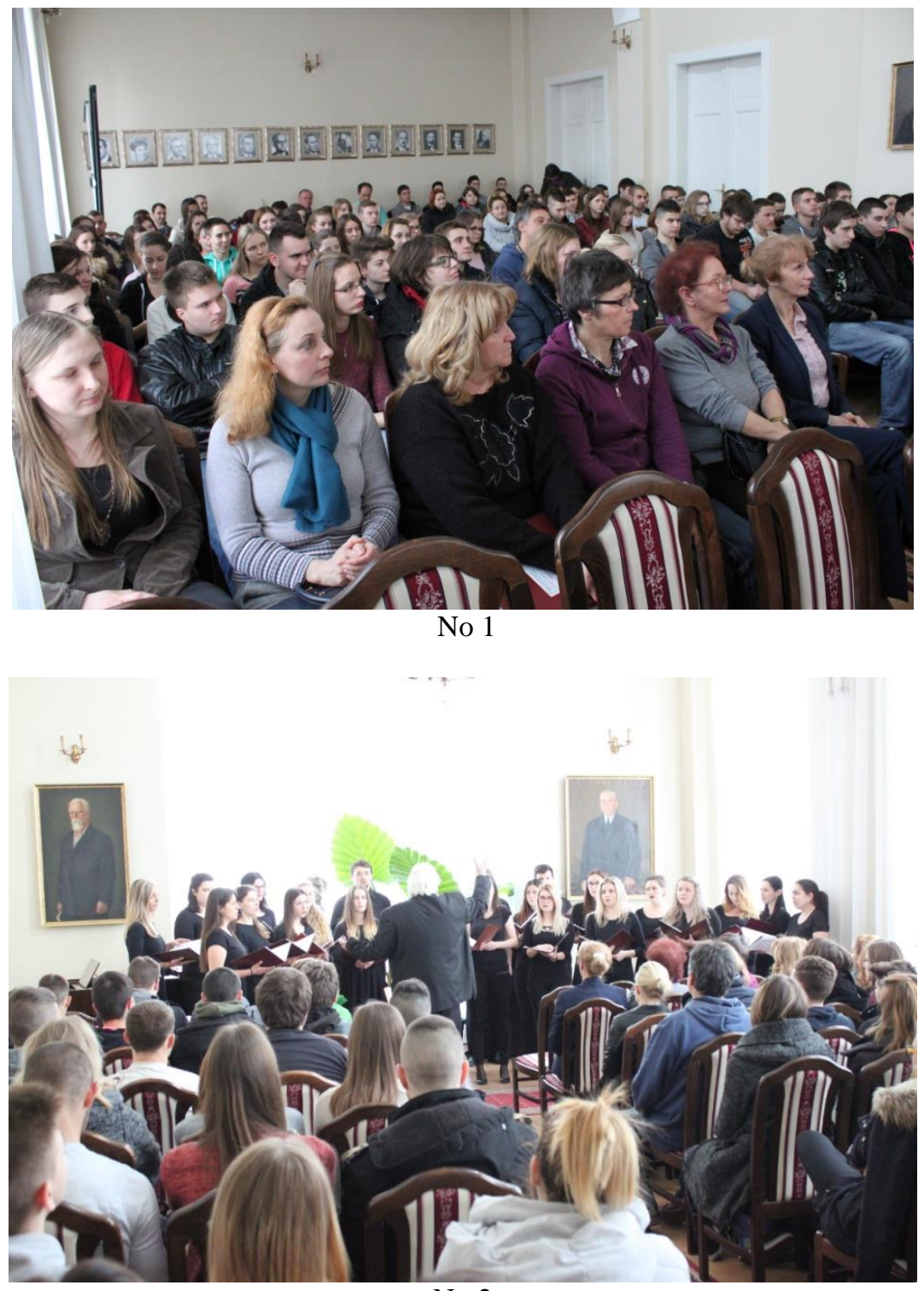


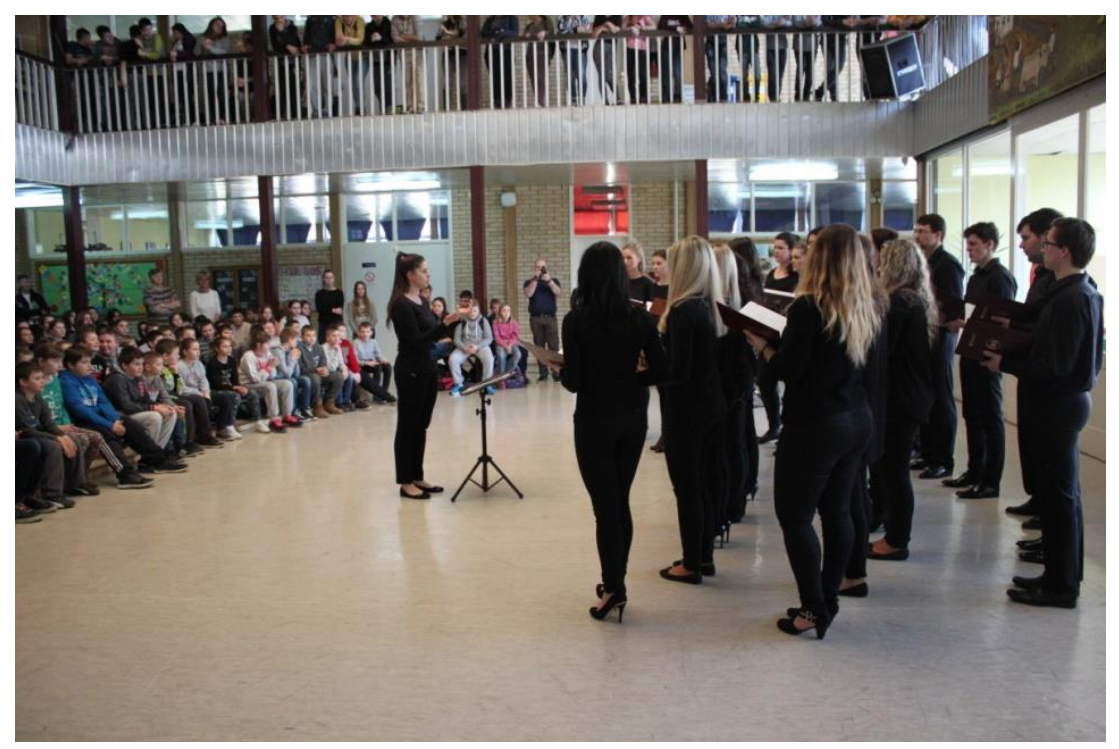

\section{No 3}

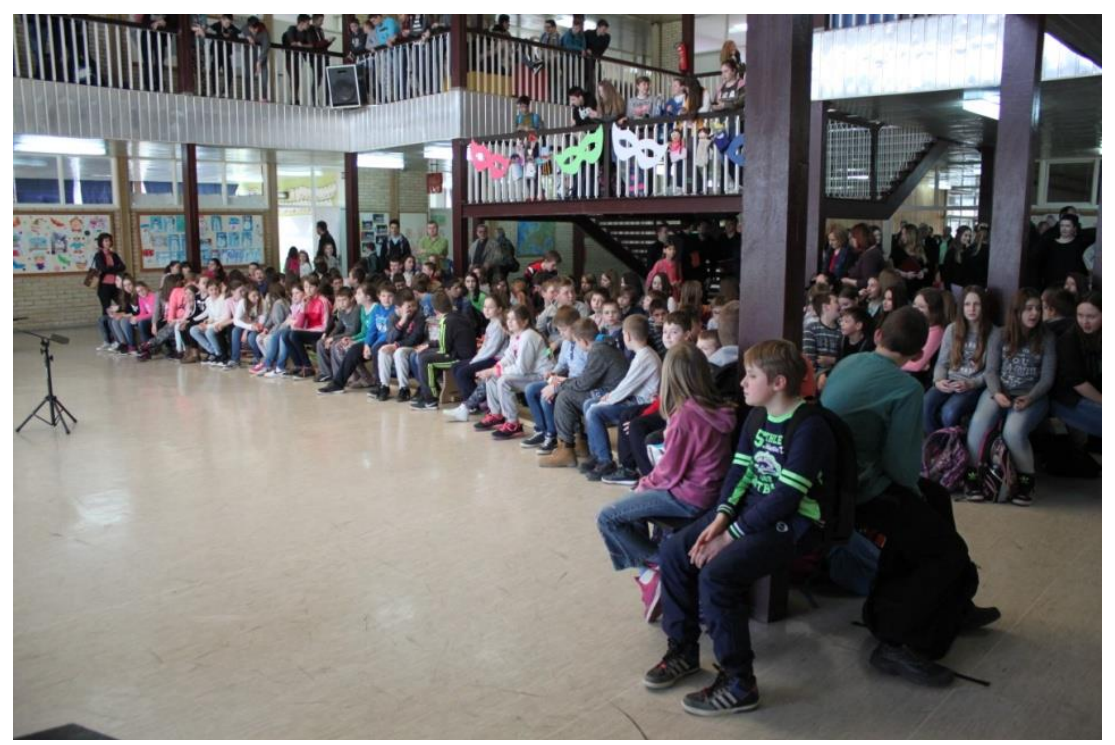

No 4 